\title{
The cytotaxonomy of four Tasmanian genera of Proteaceae
}

\author{
Robert J.E. Wiltshire and Helen M. Stace
}

\begin{abstract}
Wiltshire, R.J.E. ${ }^{1}$ and Stace, H.M. ${ }^{2}\left({ }^{1}\right.$ Department of Plant Science, University of Tasmania, GPO Box 25255, Hobart, Tasmania 7001, ${ }^{2}$ Department of Botany, University of Western Australia, Nedlands, WA 6907) 1997. The cytotaxonomy of four Tasmanian genera of Proteaceae. Telopea 7(3): 181-185. New chromosome number determinations for Orites diversifolia $(2 n=28)$ and Cenarrhenes nitida $(2 n=26)$ correct prior reports. We confirm Agastachys odorata with $2 n=26$ and Bellendena montana with $2 n=10$. These data indicate that $x=15$ is absent from subfamily Grevillioideae and family Proteaceae, and $x=14$ is absent from tribe Conospermeeae of subfamily Proteoideae, but $x=5$ is confirmed in subfamily Bellendenoideae.
\end{abstract}

\section{Introduction}

In Proteaceae the highest and the lowest chromosome base numbers were reported from two Tasmanian species, $n=15$ in Orites diversifolia and $n=5$ in Bellendena montana (Venkata Rao 1957a, 1957b, 1971). All other chromosomal reports in 65 genera of the family range between $x=14$ and $x=7$ (e.g. de Vos 1943; Darlington and Wylie 1955; Smith-White 1959; Ramsay 1963; Johnson and Briggs 1963, 1975). The two results have never been revisited, although that for O. diversifolia is discordant with other data in the genus Orites (otherwise $n=14$ ), and that for the Tasmanian endemic Bellendena is unusual in the subfamily Persoonioideae (usually $x=7$ ) in which it was formerly included (Weston 1995). Another Tasmanian endemic, Cenarrhenes nitida, was reported as $n=14$ (Ramsay 1963), a generally rare result in the tribe Conospermeeae and subfamily Proteoideae which includes a further Tasmanian endemic Agastachys odorata with $2 n=26$ (Venkata Rao 1957a). All four genera, of which three are monospecific, are included in cladistic studies of Proteaceae (Douglas pers. comm.). Accurate knowledge of cytological character states is relevant for interpreting phylogenetic hypotheses of relationship among primitive and advanced taxa of Proteaceae (SmithWhite 1959; White 1978).

\section{Methods}

Fresh seeds of $O$. diversifolia were obtained from two localities in the vicinity of Hobart (Table 1), and germinated on moist filter paper. Root-tips were taken from C. nitida grown at the University of Tasmania. Rooted cuttings of B. montana were supplied by Royal Botanic Gardens, Hobart. Excised root-tips were pre-treated for 2.5 hours in saturated aqueous p-dichlorobenzene (BDH chemicals) or bromo-naphthalene, then fixed in 3:1 ethanol: acetic acid for $24 \mathrm{~h}$, stored at $4^{\circ} \mathrm{C}$ in $70 \%$ ethanol, and stained overnight at $60^{\circ} \mathrm{C}$ with Snow's alcoholic carmine. Root-tip squashes were examined and cells in mitotic metaphase were photographed by Zeiss Axiophot bright-field microscopy using Kodak Imagelink ASA 6 film. 


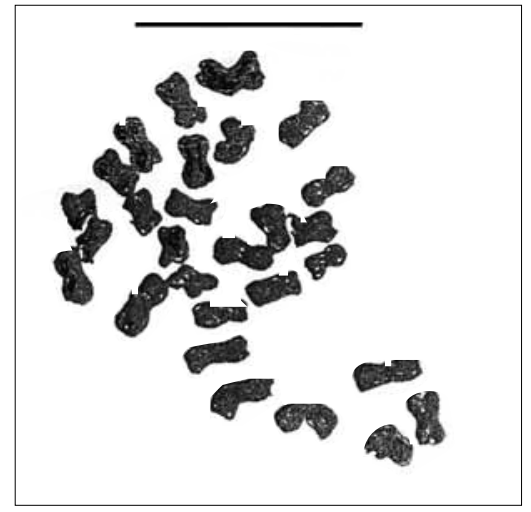

a

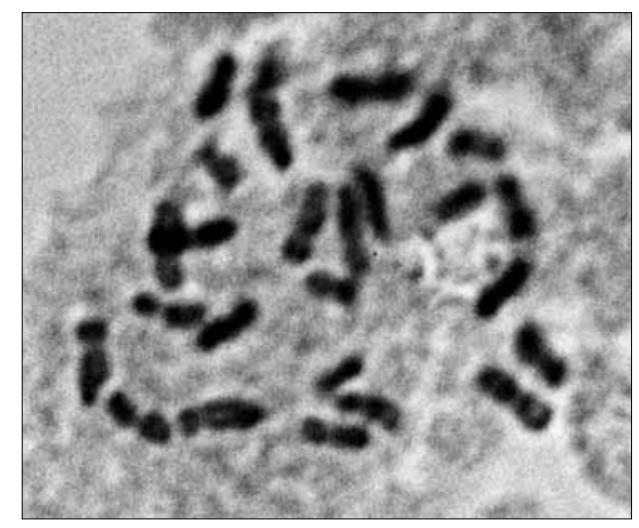

C
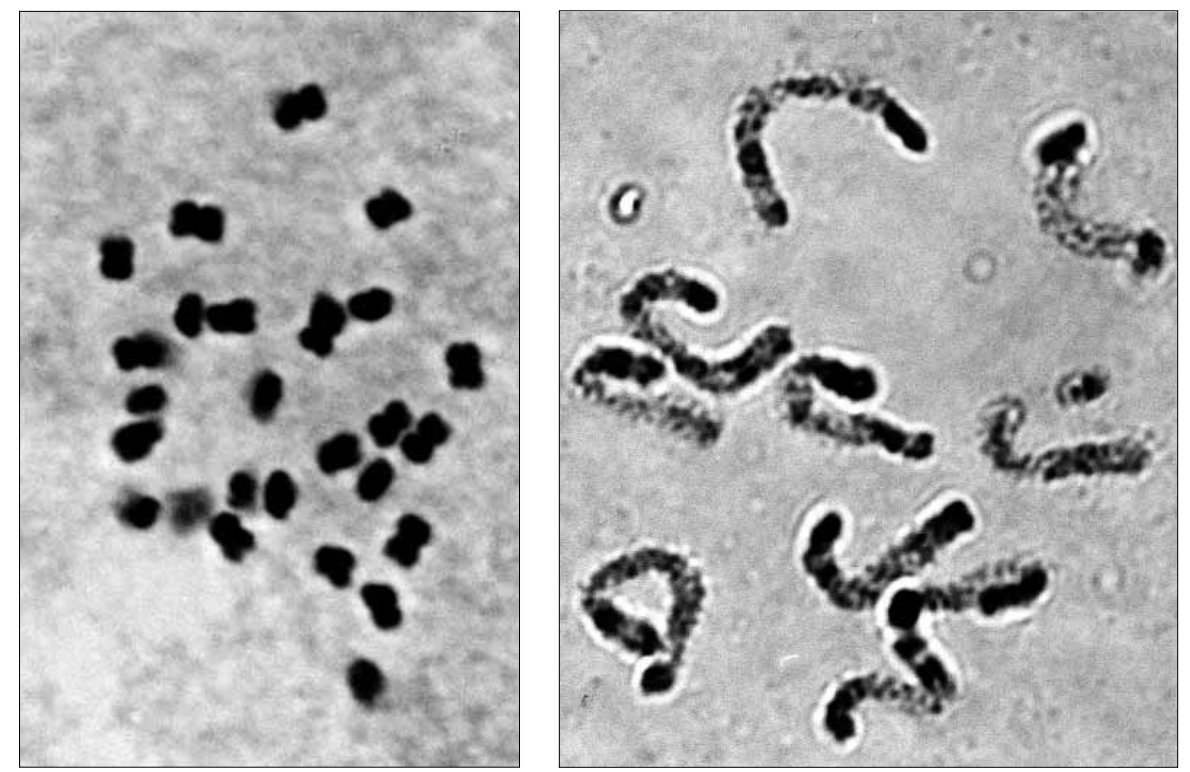

b

d

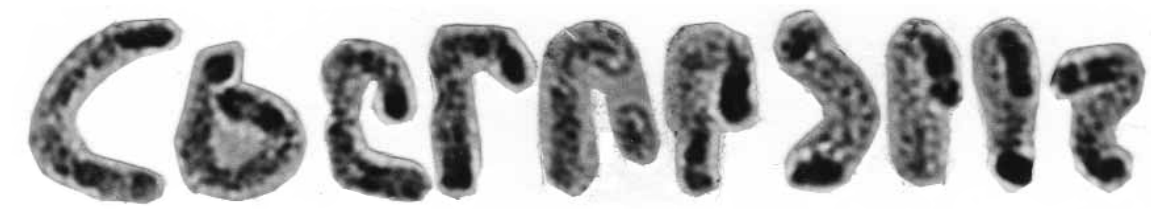

e

Fig. 1. Chromosomes in root-tip mitosis, all to similar scale (bar $=10 \mu \mathrm{m})$, with mean and total lengths of chromosomes in metaphase cells. a, Orites diversifolia $(2 \mathrm{n}=28)$, mean $2.2 \mu \mathrm{m}$, total $61 \mu \mathrm{m}$, drawn from photograph. $\mathbf{b}$, Cenarrhenes nitida $(2 \mathrm{n}=26)$, mean $1.8 \mu \mathrm{m}$, total $48 \mu \mathrm{m}$. c, Agastachys odorata $(2 \mathrm{n}=26)$, mean $3.1 \mu \mathrm{m}$, total $81 \mu \mathrm{m}$. d, e, Bellendena montana $(2 \mathrm{n}=10)$, same cell, late prophase. 


\section{Results}

Cells of $O$. diversifolia showed a maximum of $2 n=28$ well-stained chromosomes from both localities, and cells of $C$. nitida and $A$. odorata each had a maximum of $2 n=26$ chromosomes (Table 1). Metaphase chromosome sizes were relatively small (means 1.8-3.1 $\mu \mathrm{m}$ ) and, allowing for differential contraction, were quite similar in all three species (Fig. $1 \mathrm{a}, \mathrm{b}, \mathrm{c}$ ) having a combined average total genome length of $63 \mu \mathrm{m}$ (range 48-81 $\mu \mathrm{m})$. Chromosome lengths such as these are typical for Grevillioideae and Proteoideae (Ramsay 1963; Johnson and Briggs 1963, 1975; Rourke 1972).

Cells from $B$. montana had $2 n=10$ chromosomes, those in late prophase were very long (10-15 $\mu \mathrm{m})$, with a single markedly trabanted chromosome and possibly other heteromorphisms (Fig. 1 d, e). More contracted chromosomes of metaphase cells (not shown, mean chromosome length $6.7 \mu \mathrm{m}$ ) suggested three pairs of metacentrics and two shorter pairs of sub-telocentrics, but a complete karyotype of B. montana requires further study. However a preliminary assessment of the metaphase genome length of B. montana (total $67 \mu \mathrm{m}$ ) is close to the average for the previous three species with $2 n=28$ or $2 n=26$.

Table 1. New cytological reports for Tasmanian Proteaceae

$\begin{array}{lll}\text { Species } & \text { 2n } & \text { Locality and voucher } \\ \text { Orites diversifolia R.Br. } & 28 & \text { Snug Tiers, Tasmania (RJEW s.n., June 1996) } \\ & \text { c.28 } & \text { Hartz, Tasmania (RJEW s.n., June 1996) } \\ \text { Cenarrhenes nitida Labill. } & 26 & \begin{array}{l}\text { Bennetts Road, Hartz Mt., Tasmania (J. Read s.n.), cultivated at } \\ \text { Department of Plant Science, University of Tasmania }\end{array} \\ \text { Agastachys odorata R.Br. } & 26 & \text { Mt. Wellington, Tasmania (RJEW s.n., December 1996) } \\ \text { Bellendena montana R.Br. } & 10 & \text { Pine Lake, Central Plateau, Tasmania (RBG Hobart 96-113) }\end{array}$

\section{Discussion}

The finding of $2 n=28(x=14)$ for O. diversifolia from localities around Hobart is entirely consistent with other data for Orites, indeed for the tribe Oriteae including Neorites, all $x=14$ (Venkata Rao 1957a, b; Johnson and Briggs 1975). This discounts the earlier report of $n=15$ for the species from near Hobart and in this respect O. diversifolia does not differ from other Orites species. In subfamily Grevillioideae the abundant $x=14$ is probably primitive (Smith-White 1959, Johnson and Briggs 1963), as supported by cytoevolutionary interpretations of recent phylogenetic studies (Douglas pers. comm.).

The provenance of Ramsay's $n=14$ C. nitida collection was stated as 'Tasmania. Wild.' and is not exactly replicable. The new result of $2 n=26(x=13)$ for the monotypic Cenarrhenes is relatively frequent in subfamily Proteoideae. Thus, outside subfamily Grevillioideae, $x=14$ is less common in Proteaceae than was previously thought (e.g. Stace 1995). In some recent phylogenetic models Cenarrhenes plus the New Caledonian Beauprea $(x=11)$ and Beaupreopsis $(x=11)$ are basal genera in Proteaceae that separate before the better resolved 'subfamily' clades and hence may be paraphyletic to subfamily Proteoideae (Douglas pers. comm.).

In taxonomic and phylogenetic treatments (Johnson and Briggs 1975; Douglas pers. comm.) the Tasmanian monotypic Agastachys $(x=13)$ is always closely associated with the mainland genus Symphionema $(x=10)$. Although this generic grouping may be basal in the subfamily Proteoideae, other genera suggest that $x=13$ and not $x=10$ may be plesiomorphic in this subfamily. 
The $2 n=10$ from presumably a second locality for B. montana confirms the original report of $n=5$. The few but large chromosomes of Bellendena possibly constitute an advanced karyotype in Proteaceae (Johnson and Briggs 1975; White 1978; James 1981; Weston 1994), perhaps by a process of amalgamating smaller but more numerous chromosomes similar to those of the previous three taxa. However, Bellendena is now placed in the monotypic subfamily Bellendenoideae (Weston 1995) and is suggested to be the sister group to all other Proteaceae (Douglas pers. comm.). The apparently basal position of Bellendena in Proteaceae raises the question of the evolution of its unique karyotype. Is this a very primitive genome in Proteaceae, or is it an ancient but specialised genome and relictual from a much larger and cytologically more diverse group? Karyotypic comparison of Bellendenoideae $(x=5)$ with another cytologically distinctive subfamily Persoonioideae $(x=7)$ may clarify aspects of the evolution of their respectively few but large chromosomes in relation to those of other Proteaceae $(x=14,13,12,11,10)$. The genera of Proteaceae from Tasmania reported here with $x=14$, 13 and 5, in three subfamilies Grevillioideae, Proteoideae and Bellendenoideae, indicate that early Gondwanan radiations of the family were associated with considerable chromosomal evolution.

\section{Acknowledgments}

We thank RBG Hobart and Greg Jordan for supplying plant materials, and Andrew Douglas, Bill Jackson and René Vaillancourt for discussions.

\section{References}

Darlington, C.D. and Wylie, A.P. (1955) Chromosome Atlas of Flowering Plants (Allen \& Unwin: London).

de Vos, M.P. (1943) Cytological studies in genera of the Proteaceae, South African Journal of Science 40: $113-122$.

James, S.H. (1981) Cytoevolutionary patterns, genetic systems and the phytogeography of Australia. Pp. 761-782 in A. Keast (ed.), Ecological Biogeography of Australia, Vol. 1. (W. Junk: The Hague.)

Johnson, L.A.S. and Briggs, B.G. (1963) Evolution in the Proteaceae, Australian Journal of Botany 11: 21-61.

Johnson, L.A.S. and Briggs, B.G. (1975) On the Proteaceae - the evolution and classification of a southern family, Botanical Journal of the Linnean Society 70: 83-182.

Ramsay, H.P. (1963) Chromosome numbers in the Proteaceae, Australian Journal of Botany 11: $1-20$.

Rourke, J.P. (1972) Taxonomic studies on Leucospermum R. Br, Journal of South African Botany Supplementary, Vol. 8: 1-172.

Smith-White, S. (1959). Cytological evolution in the Australian flora, Cold Spring Harbor Symposium in Quantitative Biology 24: 273-289.

Stace, H.M. (1995) Primitive and advanced character states for chromosome number in Gondwanan angiosperm families of Australia, especially Rutaceae and Proteaceae. Pp. 223-232 in P.E. Brandham and M.D. Bennett (eds), Kew Chromosome Conference IV. (Royal Botanic Gardens: Kew.)

Venkata Rao, C. (1957a) Cytotaxonomic studies in Proteaceae. Ph.D. thesis, University of Tasmania, Hobart.

Venkata Rao, C. (1957b) Cytotaxonomy of the Proteaceae, Proceedings of the Linnean Society of New South Wales 82: 257-271.

Venkata Rao, C. (1971) Proteaceae. Botanical Monographs 6. (CSIR: New Delhi).

Weston, P.H. (1994) The Western Australian species of subtribe Persooniinae (Proteaceae: Persoonioideae: Persoonieae). Telopea 6: 51-165. 
Weston, P.H. (1995) Subfam. 2. Bellendenoideae. Pp. 125-127 in Flora of Australia, Vol. 16. Eleaginaceae Proteaceae, (Australian Biological Resources Study: Canberra)

White, M.J.D. (1978) Modes of Speciation (W. H. Freeman: San Francisco.)

Manuscript received 26 February 1997

Manuscript accepted 15 August 1997 
